\title{
First molecular detection of Rickettsia sp. strain Atlantic rainforest in Amblyomma ovale ticks from Espírito Santo state, Brazil
}

Primeira detecção molecular da Rickettsia sp. cepa Mata Atlântica em carrapatos Amblyomma ovale do estado
do Espírito Santo, Brasil Igor da Cunha Lima Acosta ${ }^{1}$; Hermes Ribeiro Luz; Álvaro Adolfo Faccini-Martínez ${ }^{3,4 *}$; Sebastián Muńoz-Leal'; Crispim Cerutti Junior ${ }^{3}$; Marcelo Bahia Labruna ${ }^{1}$

\begin{abstract}
${ }^{1}$ Departamento de Medicina Veterinária Preventiva e Saúde Animal, Faculdade de Medicina Veterinária e Zootecnia, Universidade de São Paulo - USP, São Paulo, SP, Brasil

${ }^{2}$ Departamento de Parasitologia Animal, Universidade Federal Rural do Rio de Janeiro - UFRRJ, Seropédica, RJ, Brasil

${ }^{3}$ Programa de Pós-graduação em Doenças Infecciosas, Centro de Ciências da Saúde, Universidade Federal do Espírito Santo - UFES, Vitória, ES, Brasil

${ }^{4}$ Comité de Medicina Tropical, Zoonosis y Medicina del Viajero, Asociación Colombiana de Infectología, Bogotá, DC, Colombia
\end{abstract}

Received January 25, 2018

Accepted February 16, 2018

\begin{abstract}
Espírito Santo state (southeastern Brazil) is considered an endemic area for spotted fever group rickettsioses. In February 2017, we received in our laboratory seven unfed Amblyomma ovale adult ticks collected by a farmer from his clothes and body (not attached) during a working day in the rural area of Ibiraçu municipality, Espírito Santo state. By polymerase chain reaction (PCR) analyses, targeting gltA and ompA rickettsial genes, the DNA of Rickettsia was detected in 6/7 (85.7\%) A. ovale. In all cases, DNA sequencing of PCR products revealed that consensus sequences of both genes were $100 \%$ identical to $g l t A$ and $o m p A$ corresponding sequences of Rickettsia sp. strain Atlantic rainforest retrieved from GenBank. This study reports the first molecular detection of Rickettsia sp. strain Atlantic rainforest in A. ovale ticks from Espírito Santo state. Our findings indicate a new Brazilian state in the southeast region at risk of human infection with this tick-borne emerging rickettsial agent.
\end{abstract}

Keywords: Rickettsia sp., strain Atlantic rainforest, Amblyomma ovale, ticks, Espírito Santo, Brazil.

\section{Resumo}

O estado do Espírito Santo (Sudeste do Brasil) é considerado área endêmica para riquetsioses do Grupo Febre Maculosa. Em fevereiro de 2017, recebemos em nosso laboratório sete carrapatos adultos Amblyomma ovale não ingurgitados, coletados por um fazendeiro nas suas roupas e corpo (não fixadas) durante um dia de trabalho, em área rural do municipio de Ibiraçu, estado do Espírito Santo. Por meio de reação em cadeia da polimerase (PCR), amplificando os genes riquetsiais gltA e ompA, foi detectado ADN de Rickettsia em 6/7 (85,7\%) dos A. ovale. O sequenciamento dos produtos de PCR indicou que as sequências consenso de ambos genes foram $100 \%$ idênticos às sequências correspondentes dos genes glt $A$ e ompA da Rickettsia sp. cepa Mata Atlântica recuperadas do GenBank. Este estudo relata a primeira detecçáo molecular da Rickettsia sp. cepa Mata Atlântica em carrapatos A. ovale do estado do Espírito Santo. Nossos resultados apontam um novo estado brasileiro da regiāo Sudeste com risco de infecção humana por este agente rickettsial emergente transmitido por carrapatos.

Palavras-chave: Rickettsia sp., cepa Mata Atlântica, Amblyomma ovale, carrapatos, Espírito Santo, Brasil. 
Spotted fever group (SFG) rickettsioses are currently recognized as emerging or re-emerging zoonotic diseases, caused by pathogenic bacteria of the genus Rickettsia and transmitted to human beings through tick bites (PAROLA et al., 2013). In Brazil, since the 1920s, Rickettsia rickettsii has been recognized as the main etiological agent of SFG rickettsioses, associated with Amblyomma sculptum (formerly Amblyomma cajennense) and Amblyomma aureolatum ticks as vectors, causing a highly lethal illness, which has been predominant by far in the southeast Brazilian region (OLIVEIRA et al., 2016). Nevertheless, in 2010, a Brazilian case of mild eschar-associated rickettsiosis was reported from the littoral region of Sáo Paulo state, and the molecular characterization of its etiological agent revealed another SFG agent, which was named the Rickettsia sp. strain Atlantic rainforest (SPOLIDORIO et al., 2010b). After this report, new human cases related to Rickettsia sp. Atlantic rainforest have been documented from Brazilian patients from Bahia and Santa Catarina states (SILVA et al., 2011; KRAWCZAK et al., 2016c). Research to unveil its epidemiology has identified the tick Amblyomma ovale as its main vector (KRAWCZAK et al., 2016a). The results based on experimental models and field-collected material indicate that this tick species is naturally infected with strain Atlantic rainforest in several states of the south (Rio Grande do Sul, Santa Catarina and Paraná), southeast (São Paulo and Rio de Janeiro) and northeast (Bahia and Ceará) regions of Brazil (KRAWCZAK et al., 2016b; NIERI-BASTOS et al., 2016; MOERBECK et al., 2016; LUZ et al., 2017).

Espírito Santo state (southeastern Brazil) is considered an endemic area for SFG rickettsioses (OLIVEIRA et al., 2016). Previously published reports, based on serological, immunohistochemical, and epidemiological methods, have suggested $R$. rickettsii as the probable etiological agent of an outbreak in the 1990s (COREY et al., 1993; SPOLIDORIO et al., 2010a). Consequently, we recently confirmed $R$. rickettsii as the etiological agent of fatal SFG rickettsiosis in human patients from Espírito Santo state between 2015 and 2017 (FACCINI-MARTÍNEZ et al., 2018). The aim to determine the identity of other pathogenic SFG rickettsiae circulating in Espírito Santo prompted the current study.

In February 2017, we received in our laboratory seven unfed adult ticks (stored in a plastic vial with $70 \%$ ethanol) that were collected by a farmer from his clothes and body (not attached) during a working day in the rural area of Ibiraçu municipality, Espírito Santo state (Figure 1). Ticks were identified following a taxonomic key for the Amblyomma genus (BARROS-BATTESTI et al., 2006) and tested for rickettsial DNA. For this purpose, ticks were processed individually for DNA extraction using the guanidine isothiocyanate phenol technique (SANGIONI et al., 2005). Then, the obtained material was tested by the polymerase chain reaction (PCR) technique using primers CS-78 and CS-323 targeting a 401-bp fragment of the citrate synthase gene $(g l t A)$, which is common in all representatives of the genus Rickettsia (LABRUNA et al., 2004). Samples yielding expected size amplicons were subsequently tested with primers $\operatorname{Rr} 190.70$ p and $\operatorname{Rr} 190.701 \mathrm{n}$, targeting a 631-bp fragment of the rickettsial $190-\mathrm{kDa}$ outer membrane protein gene $(o m p A)$ (EREMEEVA et al., 2006). The negative control tube containing ultrapure water and a positive control tube containing DNA of the Rickettsia sp. strain NOD were included in each PCR run. The obtained amplicons were purified with ExoSap (USB,
Cleveland, Ohio, USA) and DNA-sequenced in an ABI automated sequencer (Applied Biosystems/Thermo Fisher Scientific, model ABI 3500 Genetic Analyzer, Foster City, California, USA) with the same primers used for PCR. The obtained sequences were assembled with Geneious R9 software and submitted to Blast analyses (NCBI, 2017) to infer the closest similarities available in GenBank.

All seven adult ticks were morphologically identified as $A$. ovale (4 males and 3 females). Six ticks (85.7\%) were found to contain rickettsial DNA by PCR protocols targeting $g l t A$ and $o m p A$ genes. The obtained partial sequences of the $g l t A$ gene $(350-b p)$ were identical to each other, and identical sequences of $o m p A$ gene (590-bp) were obtained for all ticks as well. Consensus sequences of both genes were $100 \%$ identical to $g l t A$ and $o m p A$ corresponding sequences of Rickettsia sp. strain Atlantic rainforest (GenBank accession numbers KJ174527 and KJ158741, respectively). The DNA sequences generated in the present study have been submitted to GenBank (accession numbers MF536974, MF536975).

The present study reports for the first time the detection and molecular characterization of the Rickettsia sp. strain Atlantic rainforest in $A$. ovale ticks in the Espírito Santo state. Interestingly, the ticks tested in our study were collected from the clothes and body of a farmer, and although they were not found attached to his skin, our findings indicate an eventual risk for a possible tick bite and related pathogenic Rickettsia transmission. This is because $A$. ovale is recognized as both an anthropophilic tick in South America (GUGLIELMONE et al., 2006) and a competent vector for Rickettsia sp. strain Atlantic rainforest (KRAWCZAK et al., 2016a). Furthermore, our data identified an additional location (Ibiraçu municipality) in the state of Espírito Santo where $A$. ovale was present. In a recent study on tick fauna in the same state, $A$. ovale was only documented for the municipalities of Santa Teresa and Santa Maria de Jetibá (ACOSTA et al., 2016). Nevertheless, it is quite likely that its distribution would be even broader in Espírito

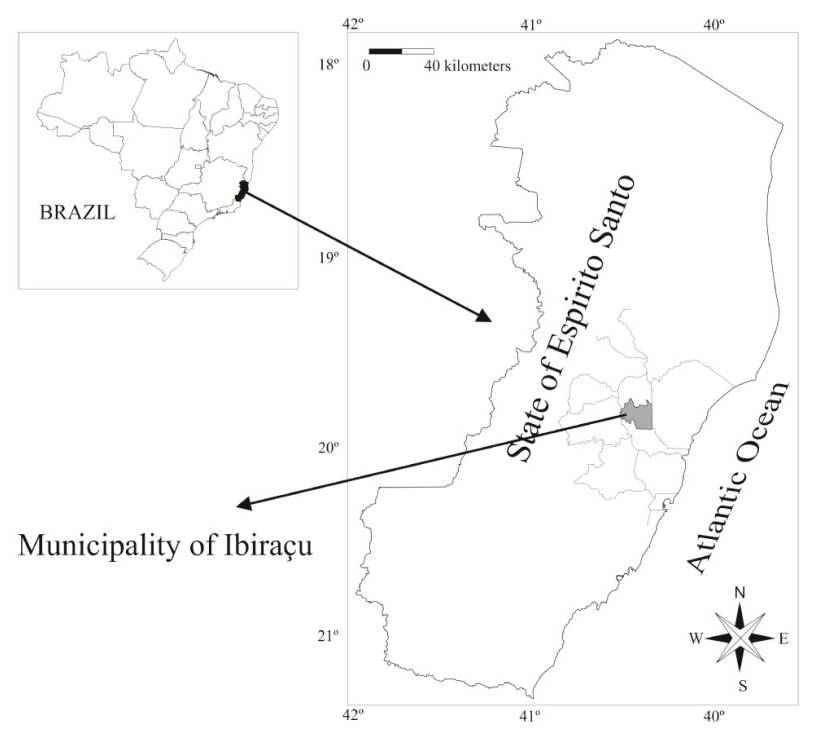

Figure 1. Map of Ibiraçu municipality in Espírito Santo state, Brazil. 
Santo since this state has an important portion of the preserved Atlantic rainforest.

Finally, our findings note a new Brazilian state within the southeast region in which the risk of human infections with Rickettsia sp. strain Atlantic rainforest, an agent of an emerging tick-borne human disease, exist. A recent study provided phylogenetic evidence that the Rickettsia sp. strain Atlantic rainforest represents a genetic variant of the human pathogen Rickettsia parkeri (PADDOCK et al., 2017). In this way, it would be important to conduct an active epidemiological search with the purpose of characterizing new eschar-associated rickettsiosis cases in Brazil.

\section{References}

Acosta ICL, Martins TF, Marcili A, Soares HS, Krawczak FS, Vieira FT, et al. Ticks (Acari: Ixodidae, Argasidae) from humans, domestic and wild animals in the state of Espírito Santo, Brazil, with notes on rickettsial infection. Vet Parasitol Reg Stud Rep 2016; 3-4: 66-69.

Barros-Battesti DM, Arzua M, Bechara GH. Carrapatos de importancia médico-veterinária da Regiāo Neotropical: um guia ilustrado para identificação de espécies. São Paulo: Vox/ICTTD-3)/Butantan; 2006.

Corey GR, Sexton DJ, Walker DH, Breitschwerdt EB, Muniz M, Dietze $\mathrm{R}$, et al. Brazilian spotted fever in Espirito Santo, Brazil: description of a focus of infection in a new endemic region. Am J Trop Med Hyg 1993; 49(2): 222-226. http://dx.doi.org/10.4269/ajtmh.1993.49.222. PMid:8357085.

Eremeeva ME, Bosserman EA, Demma LJ, Zambrano ML, Blau DM, Dasch GA. Isolation and identification of Rickettsia massiliae from Rhipicephalus sanguineus Ticks collected in Arizona. Appl Environ Microbiol 2006; 72(8): 5569-5577. http://dx.doi.org/10.1128/AEM.00122-06. PMid:16885311.

Faccini-Martínez ÁA, Muñoz-Leal S, Acosta ICL, Oliveira SV, Lima Duré AÍ, Cerutti C Jr, et al. Confirming Rickettsia rickettsii as the etiological agent of lethal spotted fever group rickettsiosis in human patients from Espírito Santo state, Brazil. Ticks Tick Borne Dis 2018. In press. http:// dx.doi.org/10.1016/j.ttbdis.2018.01.005. PMid:29371125.

Guglielmone AA, Beati L, Barros-Battesti DM, Labruna MB, Nava S, Venzal JM, et al. Ticks (Ixodidae) on humans in South America. Exp Appl Acarol 2006; 40(2): 83-100. http://dx.doi.org/10.1007/s10493006-9027-0. PMid:17103085.

Krawczak FS, Agostinho WC, Polo G, Moraes-Filho J, Labruna MB. Comparative evaluation of Amblyomma ovale ticks Infected and noninfected by Rickettsia sp. strain Atlantic rainforest, the agent of an emerging rickettsiosis in Brazil. Ticks Tick Borne Dis 2016a; 7(3): 502-507. http:// dx.doi.org/10.1016/j.ttbdis.2016.02.007. PMid:26895674.

Krawczak FS, Binder LC, Oliveira CS, Costa FB, Moraes-Filho J, Martins TF, et al. Ecology of a tick-borne spotted fever in southern Brazil. Exp Appl Acarol 2016b; 70(2): 219-229. http://dx.doi.org/10.1007/s10493016-0070-1. PMid:27392739.

Krawczak FS, Muñoz-Leal S, Guztzazky AC, Oliveira SV, Santos FC, Angerami RN, et al. Rickettsia sp. strain Atlantic rainforest infection in a patient from a spotted fever-endemic area in southern Brazil. Am J Trop Med Hyg 2016c; 95(3): 551-553. http://dx.doi.org/10.4269/ ajtmh.16-0192. PMid:27325804.
Labruna MB, Whitworth T, Bouyer DH, McBride J, Camargo LM, Camargo EP, et al. Rickettsia bellii and Rickettsia amblyommii in Amblyomma ticks from State of Rondônia Western Amazon, Brazil. J Med Entomol 2004; 41(6): 1073-1081. http://dx.doi.org/10.1603/0022-2585-41.6.1073. PMid:15605647.

Luz HR, Faccini JLH, McIntosh D. Molecular analyses reveal an abundant diversity of ticks and rickettsial agents associated with wild birds in two regions of primary Brazilian Atlantic Rainforest. Ticks Tick Borne Dis 2017; 8(4): 657-665. http://dx.doi.org/10.1016/j.ttbdis.2017.04.012. PMid:28479066.

Moerbeck L, Vizzoni VF, Machado-Ferreira E, Cavalcante RC, Oliveira SV, Soares CA, et al. Rickettsia (Rickettsiales: Rickettsiaceae) vector biodiversity in high altitude Atlantic forest fragments within a semiarid climate: a new endemic area of spotted-fever in Brazil. J Med Entomol 2016; 53(6): 1458-1466. http://dx.doi.org/10.1093/jme/tjw121. PMid:27480099.

National Center for Biotechnology Information - NCBI. Basic Local Alignment Search Tool [online]. Bethesda; 2017 [cited 2018 Jan 25]. Available from: www.ncbi.nlm.nih.gov/blast

Nieri-Bastos FA, Horta MC, Barros-Battesti DM, Moraes-Filho J, Ramirez DG, Martins TF, et al. Isolation of the pathogen Rickettsia sp. strain Atlantic rainforest from its presumed tick vector Amblyomma ovale (Acari: Ixodidae), from two areas of Brazil. J Med Entomol 2016; 53(4): 977-981. http://dx.doi.org/10.1093/jme/tjw062. PMid:27146681.

Oliveira SV, Guimarães JN, Reckziegel GC, Neves BMC, Araújo-Vilges KM, Fonseca LX, et al. An update on the epidemiological situation of spotted fever in Brazil. J Venom Anim Toxins Incl Trop Dis 2016; 22(1): 22. http://dx.doi.org/10.1186/s40409-016-0077-4. PMid:27555867.

Paddock CD, Allerdice MEJ, Karpathy SE, Nicholson WL, Levin ML, Smith TC, et al. Unique strain of Rickettsia parkeri associated with the hard tick Dermacentor parumapertus Neumann in the Western United States. Appl Environ Microbiol 2017; 83(9): e03463-e16. http://dx.doi. org/10.1128/AEM.03463-16. PMid:28213544.

Parola P, Paddock CD, Socolovschi C, Labruna MB, Mediannikov O, Kernif T, et al. Update on tick-borne rickettsioses around the world: a geographic approach. Clin Microbiol Rev 2013; 26(4): 657-702. http:// dx.doi.org/10.1128/CMR.00032-13. PMid:24092850.

Sangioni LA, Horta MC, Vianna MC, Gennari SM, Soares RM, Galvão MA, et al. Rickettsial infection in animals and Brazilian spotted fever endemicity. Emerg Infect Dis 2005; 11(2): 265-270. http://dx.doi. org/10.3201/eid1102.040656. PMid:15752445.

Silva N, Eremeeva ME, Rozental T, Ribeiro GS, Paddock CD, Ramos EA, et al. Eschar-associated spotted fever rickettsiosis, Bahia, Brazil. Emerg Infect Dis 2011; 17(2): 275-278. http://dx.doi.org/10.3201/ eid1702.100859. PMid:21291605.

Spolidorio MG, Labruna MB, Machado RZ, Moraes-Filho J, Zago AM, Donatele DM, et al. Survey for tick-borne zoonoses in the state of Espirito Santo, southeastern Brazil. Am J Trop Med Hyg 2010a; 83(1): 201-206. http://dx.doi.org/10.4269/ajtmh.2010.09-0595. PMid:20595502.

Spolidorio MG, Labruna MB, Mantovani E, Brandão PE, Richtzenhain LJ, Yoshinari NH. Novel spotted fever group rickettsiosis, Brazil. Emerg Infect Dis 2010b; 16(3): 521-523. http://dx.doi.org/10.3201/ eid1603.091338. PMid:20202436. 